\title{
Znaczenie i przydatność diagnostyczna metaloproteinaz w raku piersi
}

\author{
Ilona Zaręba ${ }^{1 *}$, Magdalena Donejko ${ }^{2^{* *}}$, Edyta Rysiak ${ }^{1}$
}

Nowotwór piersi jest drugą przyczyną zgonów Polek z przyczyn onkologicznych. Współczesne metody diagnostyki nowotworów są niewystarczające, w związku z czym wciąż poszukuje się nowych markerów nowotworowych. Jednym z nich są metaloproteinazy macierzy zewnątrzkomórkowej (MMPs). Prawidłowa regulacja aktywności metaloproteinaz jest istotna w procesie powstawania i rozwoju nowotworu, ale też i poszczególne stadia nowotworu charakteryzują się zmianami aktywności metaloproteinaz. Szczególną rolę odgrywają MMP -1, MMP-2, MMP-8, a także MMP-9 i MMP-11, których ekspresja wiąże się ze zmniejszeniem inwazyjności nowotworu. Enzymy te stanowią istotny czynnik pozwalający określić stan zaawansowania choroby, co może w znaczącym stopniu ułatwić prognozowanie dalszego przebiegu i dobór odpowiedniej terapii.

\section{Importance and usefulness of diagnostic metaloproteinases in breast cancer}

Breast cancer is the second highest cause of death of Polish women with cancer. Modern methods for cancer diagnostics are insufficient, and therefore also for searching for new tumour markers. One is the matrix metaloproteinases (MMPs). Proper regulation of metaloproteinase activity is important in the formation and development of cancer. Also the different stages of cancer are characterized by changes in the activity of matrix metaloproteinases. Especially MMPs-1, MMP-2, MMP-8, MMP-9 and MMP-11 play a key role as their expression is associated with a reduction of tumour invasiveness. These enzymes are an important factor to determine the severity of the disease, which can significantly facilitate the further course of forecasting and selection of appropriate therapy.

NOWOTWORY Journal of Oncology 2014; 64, 6: 491-495

Słowa kluczowe: metaloproteinazy, nowotwór piersi, macierz zewnątrzkomórkowa

Key words: metaloproteinase, breast cancer, extracellular matrix

\section{Wstęp}

Rak piersi stanowi jeden z najbardziej rozpowszechnionych nowotworów w skali świata. Według niektórych danych aż 34\% kobiet żyjących ze stwierdzoną chorobą nowotworową leczy się z powodu raka piersi [1]. W Polsce jest on najczęściej występującym nowotworem złośliwym wśród kobiet. Szacuje się, że rak piersi jest powodem śmierci około 5000 kobiet rocznie w naszym kraju. Należy podkreślić, że obserwuje się wzrost zachorowalności na ten rodzaj nowotworu wśród kobiet młodych (20-49 lat) oraz w średnim wieku (50-69 lat) [1, 2]. Nowotwory gruczołu piersiowego znacznie rzadziej występują u mężczyzn i nie stanowią poważnego problemu - wg KRN w 2009 roku odnotowano 112 nowych zachorowań (współczynnik zachorowalności 0,43/100 000) [1, 2].

Głównym celem dla ochrony zdrowia staje się usprawnienie wczesnej diagnostyki choroby nowotworowej i wdrożenie skuteczniejszego leczenia [3]. W celu zmniejszenia współczynnika umieralności na raka piersi na początku 2007 roku został wprowadzony populacyjny skrining raka piersi metodą mammografii w dwóch projekcjach (o wysokiej jakości) [4, 5]. Badanie to ma na celu systematyczne

1'Zakład Chemii Leków, Wydział Farmaceutyczny z Oddziałem Medycyny Laboratoryjnej, Uniwersytet Medyczny w Białymstoku

${ }^{2}$ Samodzielna Pracownia Medycyny Estetycznej, Wydział Farmaceutyczny z Oddziałem Medycyny Laboratoryjnej, Uniwersytet Medyczny w Białymstoku

*Autorka jest uczestnikiem Środowiskowych Studiów Doktoranckich w języku angielskim (KNOW)

**Autorka jest stypendystą projektu „Studiuję, badam, komercjalizuję — program wsparcia doktorantów UMB” 
monitorowanie kobiet bez objawów klinicznych choroby. Podstawową przesłanką do wykonania takich badań jest możliwość wykrycia zmiany, zanim stanie się ona wyczuwalna. W raku piersi wielkość guza i stan węzłów chłonnych w momencie rozpoznania wpływają na przeżycie. W rezultacie wczesne wykrycie oznacza lepsze rokowanie, większą szansę na pełne wyleczenie oraz większy odsetek operacji oszczędzających pierś [5]. Jednakże metody obrazowe, do których można zaliczyć mammografię, ultrasonografię (USG), tomografię komputerową i magnetyczny rezonans jądrowy, a także inne, takie jak biopsja aspiracyjna, w przypadku niewielkich zmian ogniskowych są mało skuteczne [6]. Współczesne metody diagnostyki raka piersi są niewystarczające, w związku z czym wciąż poszukuje się nowych czynników diagnostycznych, do których zaliczamy markery nowotworowe.

Synteza markera nowotworowego w nowotworze jest znacząco wyższa od wytwarzanej w komórce prawidłowej. W przebiegu chorób nowotworowych dochodzi bardzo często do konstytutywnej ekspresji genów, których produkty w komórkach zmienionych nowotworowo pojawiają się przejściowo, a mianowicie w okresie ich rozplemu i różnicowania. Jeżeli produkty te zostaną uwolnione do płynów ustrojowych, to mogą one stać się markerami przydatnymi w rozpoznawaniu i monitorowaniu choroby nowotworowej [7]. Markery odzwierciedlają trzy zjawiska toczące się w komórkach nowotworowych: proliferację, różnicowanie oraz obumieranie, w związku z czym wykazują przydatność na poszczególnych etapach procesu diagnostycznego nowotworów, to jest: w wykrywaniu, rozpoznawaniu, określaniu stopnia zaawansowania, w lokalizowaniu zmian nowotworowych, w monitorowaniu skuteczności chemio- i radioterapii, a także w wykrywaniu wznowy [7, 8]. W diagnostyce raka piersi zastosowanie znalazły klasyczne markery nowotworowe, takie jak: CA 15-3 (Carcinoma Antigen 15-3), MCA (Mucynopodobny Antygen Towarzyszący Nowotworom) i CEA (Antygen Karcinoembrionalny) [9]. Według badań przeprowadzonych przez Śliwińską i współpracowników najbardziej przydatnym markerem jest TPA (tkankowy antygen polipeptydowy), zwłaszcza w połączeniu z CA 15-3 [10]. Do grupy markerów raka piersi zalicza się niektóre cytokiny - HGFs, M-CSF, IL-6 czy IGF-I [6].

Do znaczników nowotworowych zaliczane są również molekularne markery karcynogenezy. Rozwój nowotworu ma najczęściej związek z mutacją w pojedynczej komórce somatycznej, która prowadzi do spontanicznej transformacji nowotworowej. Znacznie rzadszym zjawiskiem, ale również występującym wśród kobiet ze zdiagnozowanym rakiem piersi, jest dziedziczne przekazywanie przez rodziców zmutowanego genu. Zmiany molekularne powstałe wskutek mutacji mogą doprowadzić do zmiany bądź zaburzenia funkcji protoonkogenów [6]. W guzach nowotworowych piersi zaobserwowano zjawisko amplifikacji niektórych onkogenów lub nadmiernej ekspresji odpowiadającego im mRNA. Do najczęściej opisywanych onkogenów ulegających powtarzalnym zaburzeniom $\mathrm{w}$ raku piersi należą: c-erbB2/HER-2/neu, c-myc, N-myc i int2 $[6,11]$.

Przyczyną nieskuteczności leczenia nowotworów jest zdolność komórek rakowych do wytwarzania przerzutów. W procesie powstawania przerzutów dużą rolę odgrywa migracja komórek nowotworowych, a co za tym idzie: degradacja macierzy zewnątrzkomórkowej przez metaloproteinazy. Dlatego też w badaniach analitycznych oznacza się stężenie i aktywność tych białek, w tym MMP-1, MMP-2, MMP-8, MMP-9 i MMP-11. Metody mające zastosowanie w tych badaniach to: metody immunohistochemiczne, immunoenzymatyczne, elektroforetycznej, reakcji łańcuchowej polimerazy i hybrydyzacji in situ. Z wykorzystaniem tych technik można odróżnić formy latentne od form aktywnych metaloproteinaz, a także oznaczyć ich lokalizację w tkance [7].

\section{Metaloproteinazy}

Metaloproteinazy macierzy zewnątrzkomórkowej, nazywane również kolagenozami lub matryksami, stanowią grupę metalozależnych enzymów proteolitycznych należących do endopeptydaz [3]. Są one wytwarzane przez większość prawidłowych komórek, m. in. przez fibroblasty, mastocyty, osteoblasty, odontoblasty, komórki dendrytyczne, komórki mikrogleju, miocyty mięśniówki gładkiej, keratynocyty oraz komórki śródbłonka. Enzymy te wydzielane są również przez komórki nacieku zapalnego, makrofagi, limfocyty T, monocyty, neutrofile i eozynofile [12,13].

Metaloproteinazy (MMPs) zostały odkryte w 1962 roku podczas badań, które miały wyjaśnić mechanizm warunkujący utratę ogona u kijanek $w$ trakcie ich rozwoju i przechodzenia w postać dojrzałą. Obecnie poznano już 66 MMPs, z czego 20 ludzkich [13]

Metaloproteinazy są enzymami o budowie wielodomenowej, złożonymi z co najmniej jednej prodomeny i domeny katalitycznej. Pomiędzy tymi częściami występuje tzw. „elastyczny łącznik" aminokwasowy. Struktury wchodzące w skład domeny katalitycznej tworzą miejsce aktywne enzymu, które determinuje swoistość substratową metaloproteinaz. Prodomena, zawierając peptyd, odpowiada za utrzymanie enzymu w postaci nieaktywnej [12]. Dodatkowo w strukturze metaloproteiny może występować domena hemopeksyny, która w niektórych przypadkach odpowiada za prawidłowe rozpoznawanie i trawienie substratu, a także, co istotne, posiada zdolność do wiązania tkankowego inhibitora metaloproteinaz (TIMP) oraz aktywacji proMMP-2 $[12,14]$. Poza metaloproteinazami typu błonowego, enzymy te wytwarzane są w komórkach w postaci preproenzymów, a następnie uwalniane do przestrzeni zewnątrzkomórkowej jako proenzymy. Aktywność metaloproteinaz w warunkach fizjologicznych kontrolowana jest na kilku etapach, m.in. na poziomie transkrypcji genów, 
translacji, aktywacji proenzymów oraz poprzez endogenne aktywatory i inhibitory - inhibitory tkankowe (TIMP) i inhibitory proteaz serynowych [3]. Wydzielanie MMP jest ściśle kontrolowane przez wiele czynników pobudzających, bądź hamujących syntezę enzymów. W tkankach aktywność MMP regulowana jest przez tkankowe inhibitory metaloproteinaz (TIMP 1-4). Mechanizm działanie TIMP polega na hamowaniu aktywacji proenzymu lub też inaktywacji aktywnego enzymu poprzez tworzeniu kompleksu TIMP-MMP [12]. Prawidłowa regulacja aktywności metaloproteinaz jest istotna w procesie powstawania i rozwoju nowotworu.

\section{Rola i znaczenie MMP}

Rak piersi wykazuje znaczne skłonności do tworzenia przerzutów, których ogniska spotyka się w kościach, płucach, wątrobie i mózgu [3]. Pod względem biologicznym, komórki nowotworowe w guzie pierwotnym charakteryzują się wysoką heterogennością, która spowodowana jest występowaniem mutacji i niestabilnością genetyczną komórek [15]. W trakcie rozwoju nowotworu złośliwego możemy wyróżnić dwa etapy - wzrost guza pierwotnego i tworzenie się przerzutów odległych. W procesie progresji nowotworu część patologicznie zmienionych komórek nabywa cechy fenotypu inwazyjnego, który warunkuje zdolność komórek nowotworowych do przemieszczania się oraz naciekania otaczających tkanek i narządów. Możliwe jest to dzięki przekroczeniu przez nowotwór barier, jakie stanowią błony podstawne i macierz zewnątrzkomórkowa. Proces ten jest wynikiem degradacji kolagenu typu IV przez metaloproteinazy, co wpływa na migrację leukocytów podczas stanów zapalnych i komórek uczestniczących w procesie morfogenezy. Cecha ta warunkuje proces angiogenezy, miejscowego wzrostu nowotworu i powstanie przerzutów. Po przekroczeniu błony podstawnej naczyń krwionośnych przez nowotwór zyskuje on możliwość tworzenia przerzutów w miejscach odległych od ogniska pierwotnego $[3,10,12,15,16]$. Jednakże, aby do tego doszło, komórki nowotworowe w procesie „intra- i ekstrawazji" muszą przekroczyć błonę podstawną, otaczającą warstwę śródbłonka naczyń. Możliwe jest to dzięki aktywacji enzymów proteolitycznych, takich jak proteinazy systemu plazminy, proteinazy serynowe oraz metaloproteinazy macierzowe [10, 15]. W rozwoju nowotworu i w powstawaniu odległych przerzutów niezwykle istotną rolę spełnia również proces angiogenezy. Wykazano, że nowotwór do dalszego wzrostu oraz progresji wymaga znacznych ilości składników odżywczych, dostarczanych przez naczynia krwionośne. W następstwie dopływu tych substancji dochodzi do syntezy nowych naczyń krwionośnych, które zapewniają wzrost, rozwój i tworzenie nacieków [17]. Proces ten jest ściśle kontrolowany zarówno przez stymulatory, jak i inhibitory. Najważniejszym czynnikiem regulującym neoangiogenezę jest naczyniowo-śródbłonkowy czynnik wzrostu - VEGF. Wartościowym wskaźnikiem nasilenia procesu nowotworze- nia naczyń krwionośnych jest marker CD34 (marker gęstości sieci mikronaczyniowej). Jego podwyższona wartość jest czynnikiem negatywnie prognostycznym dla pacjentów [17], ponadto wykazuje on korelację z VEGF [18]. Aby jednak proces tworzenia nowych naczyń krwionośnych był możliwy, musi dojść do rozkładu macierzy zewnątrzkomórkowej [3]. MMP odgrywają istotną rolę w procesie neoangiogenezy, odpowiadają one za degradację czynników antyangiogennych (inhibitorów angiogenezy), takich jak nabłonkowy barwnik siatkówki (PEDF), przy czym jednocześnie stymulują proces nowotworzenia naczyń przez aktywację czynnika wzrostu śródbłonka naczyń (VEGF) oraz zasadowego czynnika wzrostu fibroblastów (bFGF), które to (VEGF i bFGF) z kolei indukują ekspresję MMP w komórkach śródbłonka [19].

Znaczącą rolę w procesie nowotworzenia odgrywa MMP-1. Podwyższony poziom tego enzymu zaobserwowano w raku piersi, przełyku i dolnego odcinka jelita grubego [20-22]. Na podstawie przeprowadzonych badań stwierdzono, że MMP-1 działa jako specyficzny aktywator dla receptorów PAR-1 (protease-activated receptor 1). Stymulacja ta prowadzi do rozrostu, a także wzrostu inwazyjności komórek rakowych [23-25]. Według niektórych badań wysoki poziom MMP-1 może powodować skrócenie czasu przeżycia u chorych na raka piersi bez nawrotu choroby oraz być przyczyną gorszego rokowania w trakcie leczenia [26-29]. Poznanie dokładnego mechanizmu warunkującego aktywację receptora PAR-1 przez MMP-1 niewątpliwie przyczyniłoby się do możliwości wprowadzenia nowej metody zapobiegającej rozrostowi komórek raka piersi.

Ważną rolę w rozroście nowotworów odgrywają również MMP-2 (żelatynaza A) i MMP-9 (żelatynaza B). Charakteryzują się one zdolnością do degradacji kolagenu typu IV, a przez to uczestniczą w mechanizmie uszkadzania błony podstawnej naczyń. W przypadku raka piersi stwierdzono podwyższony poziom metaloproteinaz oraz wzrost ich stężenia i aktywności wraz z zaawansowaniem nowotworu. Ich wzmożona ekspresja w nacieku nowotworowym jest uważana za nowy czynnik prognostyczny, ale też za czynnik monitorujący skuteczność terapii w przebiegu choroby nowotworowej. Wzrost aktywności MMP przemawia za wdrożeniem leczenia uzupełniającego w pośrednich stadiach zaawansowania choroby [30]. Z przeprowadzonych badań wynika, że u pacjentek z krótszym czasem przeżycia nastąpił wzrost poziomu MMP-2 i MMP-9 [17, 30, 31]. Dodatkowo MMP-9 powoduje spadek proliferacji limfocytów T poprzez zahamowanie reakcji odpornościowej. Wykazano również, że MMPs aktywuje TGF- $\beta$, czynnik warunkujący działanie limfocytówT, skierowane przeciw komórkom nowotworowym. Zjawiskiem towarzyszącym rozwojowi nowotworu gruczołu piersiowego jest pojawienie się komórek zapalnych, które z kolei produkują wiele różnych MMPs, m. in. MMP-9, MMP-12 i MMP-14. Sytuacja ta prowadzi do pośredniej stymulacji rozwoju nowotworu na skutek zaburzonej funkcji układu 
immunologicznego [32]. Po analizie uzyskanych wyników przez Zhang i wsp. wykazano, że aktywność kolagenazy w moczu pacjentek $z$ nowotworem piersi wzrastała przy współistniejących przerzutach [30,31], natomiast w badaniach klinicznych przeprowadzonych przez Leppa i wsp. zaobserwowano korelację pomiędzy niskim poziomem MMP-2 oraz dłuższym okresem przeżycia całkowitego i przeżyciem bez wznowy [33]. Po analizie uzyskanych wyników stwierdzono również, że pooperacyjny poziom MMP-2 jest niezależnym czynnikiem prognostycznym u chorych na raka piersi z przerzutami do węzłów chłonnych. Natomiast na podstawie pomiaru MMP-2 u tych chorych wyodrębniono grupę pacjentów z gorszym rokowaniem, kwalifikujących się do terapii adiuwantowej [33].

Przydatnym diagnostycznie markerem do oceny złośliwości raka piersi i stanu węzłów chłonnych może być także MMP-13. Do wniosków takich doszli Bin i wsp. W następstwie przeprowadzonych badań stwierdzono, że MMP13 wraz zludzkim receptorem naskórkowego czynnika wzrostu typu 2 (Her-2/neu) wykazuje pozytywną korelację w stosunku do inwazyjności raka piersi [34, 35].

Metaloproteinazy nie tylko przyczyniają się do stymulowania inwazyjności komórek rakowych. Zauważono, że MMP-8 i MMP-11 mogą pełnić odwrotną funkcję. W czasie analizy w modelu zwierzęcym stwierdzono, że enzymy te pełną funkcję ochronną i zmniejszają inwazyjność komórek nowotworowych. W wyniku głębszej analizy i poznania procesów, które warunkują to zjawisko, istnieje możliwość modulowania rozwoju nowotworu [34].

Oznaczanie poziomu aktywności metaloproteinaz odbywa się najczęściej za pomocą metody zymografii in situ. Technika ta umożliwia oznaczanie substratów w surowicy, osoczu, a także w homogenatach komórek nowotworowych [3]. Liczne doniesienia naukowe mówią o wzroście aktywności żelatynazy A i żelatynazy B w surowicy krwi w następstwie rozwoju raka piersi [36]. Poziom MMP koreluje z agresywnością guza, i co za tym idzie, z ryzykiem zgonu $[37,38]$. Enzymy te stanowią istotny czynnik pozwalający określić stan zaawansowania choroby, co może w znaczącym stopniu ułatwić prognozowanie jej przebiegu i dobór odpowiedniej terapii [3, 38].

\section{Podsumowanie}

Oznaczanie aktywności metaloproteinaz u chorych na nowotwór piersi budzi zastrzeżenia ze względu na koszt i złożoność badań, jednak aktywność tych enzymów koreluje ze stanem zaawansowania choroby, większą inwazyjnością, a także z krótszym okresem przeżycia. Dlatego też MMP są ważnym czynnikiem prognostycznym oraz monitorującym skuteczność terapii w przebiegu nowotworu piersi.

Konflikt interesu: nie zgłoszono

\section{Dr Edyta Rysiak}

Zakład Chemii Leków

Wydział Farmaceutyczny z Oddziałem Medycyny Laboratoryjnej

Uniwersytetu Medycznego w Białymstoku

ul. Mickiewicza 2D, 15-222 Białystok

e-mail:edyta.rysiak@umb.edu.pl

Otrzymano: 8 lipca 2014 r.

Przyjęto do druku: 30 września 2014 r.

\section{Piśmiennictwo}

1. Szewczyk K. Epidemiologia i profilaktyka raka piersi. W: Kornafel J (red.). Rak piersi. Warszawa: CMKP; 2011.

2. Didkowska J, Wojciechowska U, Zatoński W. Nowotwory w Polsce w roku 2009. Warszawa: Centrum Onkologii — Instytut im. Marii Skłodowskiej-Curie, 2011.

3. Śliwowska I, Kopczyński Z. Metaloproteinazy macierzy zewnątrzkomórkowej - charakterystyka biochemiczna i kliniczna wartość oznaczania u chorych na raka piersi. Wsp Onkol 2005; 9: 327-335.

4. Szynglarewicz B, Matkowski R, Kasprzak P i wsp. Skuteczność populacyjnego programu wczesnego wykrywania raka piersi. PML 2009; 26: $117-120$.

5. Wesołowska E. Badania przesiewowe w zakresie wczesnego wykrywania raka piersi. W: Meder J (red.). Podstawy onkologi klinicznej. Warszawa: CMKP; 2011.

6. Ławnicki S, Mroczko B, Szmitkowski M. Markery nowotworowe raka piersi. Post Hig Med Dośw 2004; 58: 292-300.

7. Kulpa J. Diagnostyka chorób nowotworowych. W: Dembińska-Kieć A, Naskalski W J (red.). Diagnostyka laboratoryjna z elementami biochemii klinicznej. Wrocław: Urban\&Partner; 2002, 853-883.

8. Cheung KL, Evans AJ, Robertson JF. The use of blood tumor markers in the monitoring of metastatic breast cancer unassessable for response to systemic teraphy. Breast Cancer Res Treat 2001; 67: 273-278.

9. Dmitrow SD, Matuscova E, Forejt J. Expression of BRCA 1, NRB 1 and NRB 2 genes in human breast cancer cells. Folia Biol 2001; 47: 120-127.

10. Kwiatkowski P, Godlewski J, Śliwińska-Jewsiewicka A i wsp. Rola metaloproteinaz macierzy zewnątrzkomórkowej w procesie inwazji nowotworu. Pol Ann Med. 2008; 15: 43-50.

11. Ardi VC, Kupriyanova TA, Deryugina El i wsp. Human neutrophilis uniquely release TIMP-free MMP-9 to pro vide a potent catalytic stimulator of angiogenesis. Proc Natl Acad Sci USA 2007; 104: 20262-20267.

12. Lipka D, Boratyński J. Metaloproteinazy MMP. Struktura i funkcja. Post Hig Med. Dośw 2008; 62: 328-336.

13. Jones Ch, Sane D, Herrington D. Matrix metalloproteinases: A review of their structure and role inacute coronary syndrome. Card Res 2003; 59: 812-823.

14. Visse R, Nagase H. Matrix metalloproteinases and tissue inhibitions of metalloproteinases: structure, function and biochemistry. Circ Res 2003; 92: 827-839.

15. Wideł MS, Wideł M. Mechanizmy przerzutowania i molekularne markery progresji nowotworów złośliwych. I. Rak jelita grubego. Post Hig Med Dośw 2006; 60: 453-470.

16. Egeblad $M$, Werb $Z$. New functions for the matrix metalloproteinases in cancer progression. Nat Rev Cancer 2002; 2: 161-174.

17. Pentheroudalis G, Briasoulis E, Paulidis N. Cancer of unknown primary site: missing primary or missing biology? Oncologist 2007; 12: 418-425.

18. Karavasilis V, Malamor-Mitsi V, Briasoulis E. Angiogenesis in cancer of unknown primary: Clinicopatological study of CD34, VEGF and TSP-1. BMC Cancer 2005; 5: 25-32.

19. Hrabec F, Naduk J, Stręk M i wsp. Kolagenazy typu IV (MMP-2 i MMP-9) i ich substraty - białka macierzy pozakomórkowej, hormony, cytokiny, hemokiny i ich receptory. Post Biochem 2007; 53: 37-45.

20. Wang F, He W, Fanghui P, Wang L i wsp. NF-kBP65 promotes invasion and metastasis of oesophageal squamous cell cancer by regulating matrix metalloproteinase-9 and epithelial-to-mesenchymal transition. Cell Biol Int 2013; 37: 780-788.

21. Chia CY, Kumari U, Casey PJ. Breast cancer cell invasion mediated by Ga12 signaling involves expression of interleukins- 6 and -8 , and matrix metalloproteinase-2. J Mol Signal. 2014; 17: 9-6.

22. Vasaturo F, Solai F, Malacrino C i wsp. Plasma levels of matrix metalloproteinases 2 and 9 correlate with histological grade in breast cancer patients. Oncol Lett. 2013; 5: 316-320. 
23. Minn A, Gupta G, Siegel P i wsp. Genes that mediate breast cancer metastasis to lung. Nature 2005; 436: 518-524.

24. Boire A, Covic L, Agarwal A i wsp. PAR 1 is a matrix metalloprotease-1 receptor that promotes invasion and tumorigenesis of breast cancer cells. Cell 2005; 120: 303-313.

25. Gong Y, Chippada-Venkata UD, Oh WK. Roles of matrix metalloproteinases and their natural inhibitors in prostate cancer progression. Cancers (Basel). 2014; 6: 1298-1327.

26. Karavasilis V, Malamor-Mitsi V, Briasoulis E i wsp. Matrix metaloproteinsases in carcinoma of unknown primary. Cancer 2005; 104: 2282-2287.

27. Boström $P$, Söderström M, Vahlberg T i wsp. MMP-1 expression has an independent prognostic value in breast cancer. BMC Cancer 2011; 11: 348-356.

28. McGowan PM, Duffy MJ. Matrix metalloproteinase expression and outcome in patients with breast cancer: analysis of a published database. Ann Oncol 2008; 19: 1566-1572.

29. Eck S, Hoopes P, Petrella B i wsp. Matrix metalloproteinase-1 promotes breast cancer angiogenesis and osteolysis in a novel in vivo model. Breast Cancer Res Treat 2009; 116: 79-90.

30. Łukaszewicz M, Mroczko B, Szmitkowski M. Rola metaloproteinaz i ich inhibitorów w raku trzustki. Post Hig Med. Dośw 2008; 62: 141-147.

31. Jinga D C, Blidaru A, Condrea I i wsp. MMP-9 and MMP-2 gelatinases and TIMP-1 and Timp-2 inhibitors in breast cancer: correlations with prognostic factors. J Cell Mol Med 2006; 10: 499-510.
32. Łapka A, Goździalska A, Jaśkiewicz J. Rola metaloproteinaz macierzy pozakomórkowej w nowotworach piersi, ze szczególnym uwzględnieniem roli żelatynazy A i żelatynazy B. Post Biol Kom 2006; 33: 683-695.

33. Leppa $S$, Saarto T, Vehmanen L i wsp. A high serum matrix metalloproteinase-2 level is associated with an adverse prognosis in node-positive breast carcinoma. Clin Cancer Res 2004; 10: 1057-1063.

34. Bin Z, Xuchen C, Yanxue L i wsp. Tumor-derived matrix metalloproteinase-13 (MMP-13) correlates with poor prognoses of invasive breast cancer. BMC Cancer 2008; 28: 83-90.

35. Morgia G, Falsaperla M, Malaponte G i wsp. Matrix metalloproteinases as diagnostic (MMP-13) and prognostic (MMP-2, MMP-9) markers of prostate cancer. Urol Res 2005; 33: 44-50.

36. Kopczyński Z, Śliwowska I, Grodecka-Gazdecka S. Przydatnoość testów do oznaczania stężenia tkankowego polipeptydowego antygenu (TPA), swoistego tkankowego polipeptydowego antygenu (TPS), antygenu 15-3 (CA 15-3) i oznaczania aktywności żelatynazy A (pro-MMP-2, 72 $\mathrm{kDa}$ ) i żelatynazy B (pro-MMP-9, $92 \mathrm{kDa}$ ) w różnicowaniu pierwotnego raka piersi od zmian łagodnych. Diag Lab 2004; 40: 379-387.

37. Sheen-Chen SM, Chen HS, Eng HL, Sheen CC, Chen WJ. Serum levels of matrix metalloproteinase 2 in patients with breast cancer. Cancer Lett 2001; 173: 79-82.

38. Ranuncolo SM, Armanasco E, Cresta C i wsp. Plasma MMP-9 (92 kDa-MMP) activity is useful in the follow-up and in the assessment of prognosis in breast cancer patients. Int J Cancer 2003; 106: 745-51. 